Artur Szachniewicz

Uniwersytet Jagielloński, Kraków

ORCID: 0000-0002-1678-9486

e-mail: artur.szachniewicz@gmail.com

\title{
Czas i przestrzeń w metafizyce Witkiewicza a pierwotność ontologiczna indywiduów. Ujęcie z perspektywy wybranych wątków współczesnej metafizyki analitycznej
}

DOI: http://dx.doi.org/10.12775/RF.2019.003

\section{Wstęp}

Pojęcia czasu i przestrzeni stanowią formalną charakterystykę kategorii indywiduów w systemie Stanisława Ignacego Witkiewicza. Z tego też względu zajmują kluczową pozycję w filozofii Witkiewicza. Niestety nie są one bezpośrednio podejmowane w opracowaniach filozoficznego dorobku zakopiańczyka. Stanowisko interpretacyjne przyjęte przez większość autorów opiera się na bona fide absolutystycznej interpretacji idiomu stosowanego przez Witkiewicza. W efekcie, dominujące rozumienie statusu ontologicznego czasu i przestrzeni jest obiektywistyczne i nierelacjonistyczne ${ }^{1}$. Wyraża się ono w przeświadczeniu, że w myśl tej teorii istnieje „faktycznie pusta przestrzeń, oczywiście połączona z czasem, która wypełniona jest osobnikami"2. Powszechnie uznaje się zatem, że charakteryzując model Witkiewiczowskiej metafizyki, „pojęcia

1 Bohdan Michalski, Polemiki filozoficzne Stanisława Ignacego Witkiewicza, (Warszawa: PIW, 1979), 21, 87; także: Maciej Soin, Filozofia Stanisława Ignacego Witkiewicza (Wrocław: Wydawnictwo Uniwersytetu Wrocławskiego, 2002).

2 Agnieszka Biegalska, „Filozofia przyrody w recepcji Stanisława Ignacego Witkiewicza. Czas i przestrzeń", Ruch Filozoficzny 3 (2004): 437. 
»absolutna przestrzeń «"3 nie można wyeliminować, Witkiewicz zaś był $\mathrm{w}$ istocie przekonany o istnieniu ,absolutnej Czaso-przestrzeni"4.

O ile metaforyka i idiomatyka wielu wypowiedzi Witkiewicza uzasadniają przyjęcie takiej interpretacji, to jednak nie można nie zauważyć okoliczności występowania stwierdzeń z nią niezgodnych. Jest więc prawdopodobne, że same analizy tekstualne nie wystarczą do rozstrzygnięcia tego zagadnienia. Dla ustalenia ostatecznej interpretacji pomocny mógłby okazać się teoretyczny argument świadczący na rzecz jednej $\mathrm{z}$ dwóch interpretacji. W celu przedstawienia takiego argumentu lokuję tezy Witkiewicza we współczesnej siatce pojęciowej dotyczącej pierwotności bytowej, monizmu i pluralizmu.

W prezentowanej pracy korzystam z zasobów pojęć wypracowanych przez metafizykę analityczną. Pod tym ostatnim terminem rozumiem metafizykę uprawianą $\mathrm{w}$ ramach szerokiej tradycji filozoficznej sięgającej od Gottloba Fregego, przez Bertranda Russella, Ludwiga Wittgensteina, George'a Edwarda Moore'a, Wilfrida Sellarsa aż po współczesnych filozofów głównego nurtu filozofii brytyjskiej i amerykańskiej. Taki zabieg jest uzasadniony. Związki Witkiewicza z poglądami niektórych z wymienionych powyżej są znane i miały wpływ na jego filozofię. Co więcej, problemy poruszane $\mathrm{w}$ jego filozofii dziś są podejmowane właśnie $\mathrm{w}$ ramach tej tradycji filozoficznej. $\mathrm{W}$ tej pracy nie konfrontuję jednak poglądów Witkacego w sposób systematyczny z poglądami jakiegokolwiek filozofa tego nurtu. Korzystam raczej doraźnie z wypracowanych przez nich pojęć, licząc, że mogą okazać się one pomocne w rzuceniu nowego światła na myśl Witkiewicza.

W dalszych częściach pracy proponuję dwie interpretacje Witkiewiczowskiej filozofii czasu i przestrzeni - absolutystyczną (\$2) i relacjonistyczną (§3). Następnie w (\$4) prowadzę rozważania przy użyciu kategorii pierwotności bytowej oraz monizmu i pluralizmu zapożyczonych z najnowszych rozważań z obszaru metafizyki analitycznej. Argumentuję, że absolutyzm prowadzi do sprzeczności zarówno przy założeniu pewnych wariantów monizmu, jak i pluralizmu.

Zanim jednak przejdziemy do głównych rozważań, wyjaśnienia wymaga przyjęte $\mathrm{w}$ tej pracy rozumienie terminów absolutyzmu i relacjonizmu. Współcześnie spór dotyczący natury czasu i przestrzeni (czasoprzestrzeni) realizuje się $\mathrm{w}$ dyskusji stanowisk substantywizmu i relacjonizmu ${ }^{5}$. Według substantywizmu przestrzeń i/lub czas są egzystencjalnie niezależne od obiektów lub procesów fizycznych i wy-

3 Krzysztof Kościuszko, „,Witkacy uwikłany w spór między absolutną a relacyjną teorią przestrzeni", Rocznik Podhalański XI (2016): 333.

4 Biegalska, "Filozofia przyrody”, 437.

5 Matteo Morganti, „Relational Time”, w: Metaphysics in Contemporary Physics, red. Tomasz Bigaj, Christian Wuthrich (Amsterdam: Brill Rodopi, 2015), 216. 
przedzają je w porządku bytowym. Ujmując rzecz obrazowo, można twierdzić, że stanowią one scenę, na której lokują się obiekty i procesy. Relacjonizm zaś, przeciwnie do substantywizmu, rozumie przestrzeń i/lub czas jako bytowo pochodne od obiektów lub zdarzeń fizycznych czy nawet redukowalne do relacji między nimi ${ }^{6}$.

Współcześnie więc kontrowersja dotyczy kwestii zachodzenia relacji ontologicznej zależności między obiektami lub zdarzeniami fizycznymi z jednej strony a fragmentami czasu i/lub przestrzeni (lub po prostu czasoprzestrzeni), z drugiej. Takiej ekspozycji tej debaty nie można jednak bez modyfikacji zaadaptować do rozważań dotyczących Witkiewiczowskiej ontologii ogólnej. Taki stan rzeczy wynika z często wyrażanego przez Witkiewicza przeświadczenia, że przedmiot fizyki, wraz z przestrzenią fizyczna, w której jest lokalizowany, jest bytowo pochodny od jeszcze bardziej fundamentalnej bytowo kategorii, mianowicie kategorii psychofizycznego indywiduum. Świadczą o tym wypowiedzi, takie jak choćby ta: „świat materii martwej jest sprowadzony tylko do istnienia monad różnych rzędów wielkości"7. Omawiana kontrowersja dotyczy zatem statusu i natury przestrzeni, w której trwa (na którą składa się) wielość indywiduów niebędących przedmiotami fizyki, lecz stanowiących ich fundament bytowy.

$Z$ tego też powodu dla potrzeb prezentacji omawianej opozycji lepiej stosować tradycyjne określenia, takie jak „absolutyzm” i „relacjonizm”. W myśl tej konwencji absolutysta w kwestii przestrzeni (czasu) traktuje je jako byt sui generis, niezależny od kategorii indywiduum. Relacjonista, przeciwnie, uznaje bytową zależność przestrzeni (czasu) od kategorii istnienia indywidualnego. Ostatecznie więc czas i przestrzeń mogą być określone jako konstrukt relacji, w jakie wchodzą indywidua. Na tym tle uwypukla się także zasadnicza różnica między obu stanowiskami: konsekwencją absolutyzmu w powyższym rozumieniu jest możliwość istnienia pustych obszarów przestrzeni; relacjonizm natomiast wyklucza taką możliwość.

\section{Dominujący pogląd}

Powszechnie uważa się, że teoria Witkiewicza pociąga za sobą zobowiązanie ontologicznie wobec indywiduów. Dziedzina ontologiczna tej teorii zostaje określona jako klasa desygnatów pojęcia Istnienia Poszczególnego: „Istnienie w całości składa się tylko i jedynie z Istnień

6 Morganti, „Relational Time”, 215.

7 Stanisław Ignacy Witkiewicz, "O przestrzeni”, w: Stanisław Ignacy Witkiewicz, Dzieła zebrane, t. 15, red. Maciej Dombrowski, Magdalena Bizior-Dombrowska (Warszawa: PIW, 2014), 632. 
Poszczególnych"8. Istnienie Poszczególne stanowi fundament postulowanej przez Witkacego ontologii świata rzeczywistego'. Odpowiada ono pojęciu konkretnego indywiduum psychofizycznego, monady ${ }^{10}$. Przez konkretność rozumie się, że Istnienie Poszczególne nie jest abstraktem ${ }^{11}$, indywidualność zaś odnosi się do charakteru specyficznej jedności przysługującej Istnieniu Poszczególnemu, mimo jego złożoności pod względem mereologicznym. Ponadto każde indywiduum stanowi zarazem jedność elementu psychicznego i cielesnego - jaźńn ${ }^{12}$. W konsekwencji każde indywiduum jest podmiotem atrybucji predykatów zarówno psychicznych, jak i fizycznych. Jest więc nie tylko obiektem w świecie, ale także swoistym punktem widzenia świata. Dodajmy, że chodzi o świat, którego przedmioty same są zbudowane $\mathrm{z}$ układów analogicznych indywiduów występujących w ramach głębszych poziomów bytowych nawarstwiających się ad infinitum. Dziedzina indywiduów jest zatem nieskończona i tworzy hierarchię poziomów ze względu na przedział wielkości, w którym plasują się indywidua przynależne do poszczególnych poziomów ${ }^{13}$. Na każdym z tych poziomów indywidua tworzą tzw. układy, te zaś są reprezentowane dla indywiduów odpowiednio wyższych warstw bytowych poprzez kompleksy jakości utożsamiane z doznaniami. Każde indywiduum z osobna, tak jak i wszystkie one razem, stanowią jedność $\mathrm{w}$ wielości. W pierwszym przypadku jest to monada wyższego poziomu wielkości, w drugim - całość istnienia.

8 Stanisław Ignacy Witkiewicz, „Pojęcia i twierdzenia implikowane przez pojęcie istnienia", w: Stanisław Ignacy Witkiewicz, Dzieła zebrane, t. 13, red. Bohdan Michalski (Warszawa: PIW, 2002), 170.

9 Witkiewicz, „Pojęcia i twierdzenia...”, 175; Stanisław Ignacy Witkiewicz, „Spór o monadyzm. Dwugłos polemiczny z Janem Leszczyńskim", w: Stanisław Ignacy Witkiewicz, Dzieła zebrane, t. 16, red. Bohdan Michalski (Warszawa: PIW, 2002), 186.

10 Termin „Istnienie Poszczególne” oraz równoznaczny z nim i również stosowany przez Witkiewicza termin "monada” wyrażają pojęcie psychofizycznego indywiduum. W swojej recenzji książki Witkiewicza Tadeusz Kotarbiński zainicjował stosowanie terminu „osobnik”, tak właśnie tłumacząc pierwszy termin Witkiewicza. W odpowiedzi na tę translację autor nie oponował, można więc uznać, że przekład został uznany za trafny. Por. Tadeusz Kotarbiński, „Witkiewicz Stanisław Ignacy: "Pojęcia i twierdzenia implikowane przez pojęcie Istnienia«", w: Stanisław Ignacy Witkiewicz, Dzieła zebrane, t. 13, 387.

11 Mówiąc o przykładowym Istnieniu Poszczególnym, pisze: „jesteśmy rozciągli, ciężcy i nieprzenikliwi” (Witkiewicz, "Spór o monadyzm”, 217).

12 Witkiewicz twierdzi, że jaźń jest „zmaterializowaną biologicznie entelechią" (tamże, 99). Oznacza to odrzucenie przekonania o istnieniu niekonkretnej, abstrakcyjnej duszy: „»dusza « [cudzysłów w oryginale - A.Sz.] jest właśnie zsubstancjalizowana - nazywam sam (IP) „zmaterializowaną entelechią” (tamże, 342). Wcześniej zaś stwierdza wprost, że jaźń i ciało są tym samym: „Nie ma dla mnie bezcielesnej jaźni i ciała, jest tylko cielesna jaźń. Tożsamość jest więc użyta tu w znaczeniu obejmującym i jedno, i drugie" (tamże, 341).

13 Witkiewicz, „Pojęcia i twierdzenia”, 175. 
Jako szczególne „ja” poszczególna monada przeciwstawia się „wielości Istnień Poszczególnych, składających całe istnienie"14. Całość istnienia nie ma charakteru łaźniowego i sama nie jest monadą, niemniej przejmuje istotne własności indywiduów, które się na nią składają. Witkiewicz uważa, że „istotną właściwością" indywiduów i ich agregatów jest „czasowość i przestrzenność", które „nie podlegają definicji”15. Każde indywiduum trwa $\mathrm{i}$ jest rozciągłe. Ten stan rzeczy jest możliwy dzięki czasowo-przestrzennej formie istnienia, która określa jedność formalną indywiduów: „Ponieważ każde (IP) jest ograniczeniem Formy Istnienia, więc wszystkie właściwości Formy tej, z wyjątkiem Nieskończoności w wielkości, muszą być właściwościami wszystkich (IPN)"16.

Podstawowe założenia powyższej rekonstrukcji filozofii Witkiewicza można zrekapitulować w formie następujących dwóch tez: ontologicznej (1) oraz formalnej (2).

(1) Tym, co istnieje, są indywidua.

(2) Każde indywiduum jest ograniczeniem formy istnienia.

Forma istnienia zostaje scharakteryzowana za pomocą kategorii czasu i przestrzeni ${ }^{17}$. Uwzględniając zdecydowany nominalizm Witkiewicza i jego niechęć do wszelkiej abstrakcji, wydaje się zasadne, by w myśl rekonstruowanej interpretacji czas i przestrzeń uznać za swego rodzaju konkrety. Ich bliskie powiązanie uzasadnia stosowanie terminu czaso-przestrzeni. Należy jednak zastrzec, że nie chodzi tu o pojęcie analogiczne do hiperprzestrzeni fizyki teoretycznej ${ }^{18}$, gdzie czas pełni rolę czwartego wymiaru. W ramach rekonstruowanej interpretacji wyrażoną tu myśl ujmuje teza (3):

14 Tamże, 129.

15 Tamże, 193.

16 Tamże, 185. Stosując cytaty, zachowuję oryginalne akronimy wprowadzone przez Witkiewicza: (IP) - Istnienie Poszczególne; (IPN) - liczba mnoga od (IP); (AT) - trwanie dla siebie, (ATN) - liczba mnoga od (AT); (AR) - rozciągłość dla siebie; (IPC) - Istnienie Poszczególne częściowe składające się na rozciągłość rozważanego (IP); (IPCN) - liczba mnoga od indywiduów częściowych mniejszych rozmiarów składających się na rozciągłość rozważanego (IP); $\left(\mathrm{IPCN}_{1}\right)$ - (IPCN) pierwszego rzędu wielkości wobec danego (IP); $\left(\right.$ IPCN $\left._{\infty}\right)$ - (IPCN) nieskończenie odległego rzędu wielkości.

17 ,Czas i Przestrzeń [...] stanowią dwie strony dwoistości jednej dwoistej Formy Istnienia, bez której jest ono [istnienie - A.Sz.] nie-do-przyjęcia (nie-do-pomyślenia, nie-do-wyobrażenia). [...] Czas i Przestrzeń są jedyne i tożsame ze sobą jako strony dwoistości jednej formy Istnienia” (Witkiewicz, „Pojęcia i twierdzenia”, 181).

18 Zob. tamże, 189 (przypis); także: Stanisław Ignacy Witkiewicz, „Pojęcie istnienia i wynikające z niego pojęcia i twierdzenia", w: Stanisław Ignacy Witkiewicz, Dzieta zebrane, t. $13,361$. 
(3) Formą istnienia jest czaso-przestrzeń.

Teza (3) wyraża tożsamość formy istnienia z czasoprzestrzenia, Stanowi ona uściślenie poglądu prezentowanego przez Michalskiego, który pisze o „obiektywnym istnieniu przestrzeni jako formy istnienia"19. Przekonanie o obiektywnym istnieniu czaso-przestrzeni można uznać za wynikające wprost z tych wypowiedzi Witkiewicza, w których stwierdza on istnienie ,,jednej jedynej Formy Istnienia w całości, w której jako jej ograniczenia istnieją (IPN)"20.

Powyższe tezy dostarczają wyjaśnienia twierdzeniu o rozciągłości czasowo-przestrzennej indywiduów ${ }^{21}$.

(1) Tym, co istnieje, są indywidua.

(2) Każde indywiduum jest ograniczeniem formy istnienia.

(3) Formą istnienia jest czaso-przestrzeń.

Zatem:

(4) Każde indywiduum jest ograniczeniem (częścią) czaso-przestrzeni.

W powyższej rekonstrukcji termin „ograniczenie”, stosowany już przez samego Witkiewicza, rozumiany jest jako równoznaczny z pojęciem części²2. Każde indywiduum okazuje się więc częścią czaso-przestrzeni. Ta ostatnia zaś, jako forma istnienia, rozumiana jest jako jedyny, pierwotny ontycznie konkret, z którego dopiero wyróżnia się (indywiduuje) poszczególne regiony $\mathrm{w}$ wyniku operacji ograniczania. W myśl proponowanego odczytania czaso-przestrzeń rozumiana jest jako pierwotna bytowo całość, z której wydziela się pewien wyróżniony region, zachowujący podstawowe właściwości tej dziedziny.

Podsumowując, omawiana interpretacja przyjmuje, że całość jednej czaso-przestrzeni jest bardziej fundamentalna bytowo niż jej części. Aby w ramach tego stanowiska wyjaśnić charakter przestrzenności jakiegoś wyróżnionego obszaru, należy uznać całość za pierwotną jedność, a własności przestrzenne obszaru wydzielonego ograniczenia uznać za pochodne od własności całości otoczenia, w jakim się lokuje. Jednak uznanie całości za zarazem tożsamą z jednością i pierwotną zaprzecza wielokrotnie i w różny sposób formułowanej przez Witkiewicza tezie, że istnienie możliwe jest jedynie jako wielość. Ta podstawowa

19 Michalski, „Polemiki filozoficzne”, 87.

20 Witkiewicz, „Pojęcia i twierdzenia”, 182.

21 Por. tamże, 185.

22 Takie odczytanie jest zgodne z niektórymi tezami Witkiewicza. Witkacy twierdzi, że w przestrzeni ulokowana jest wielość rozciągłych Istnień Poszczególnych (Witkiewicz, „Pojęcia i twierdzenia”, 233). Uważa także, że wielość ta „stanowi pewną całość, której elementy są jej częściami” (tamże, 177), a „pojęcie Istnienia w związku z pojęciem ograniczoności implikuje pojęcie części” (tamże, 183). 
niezgodność jest wystarczającym motywem do rozważenia alternatywnej interpretacji.

\section{Odczytanie alternatywne}

W poprzedniej części pracy pokazałem, że teza (4) stanowi charakterystykę indywiduum wyrażoną $\mathrm{w}$ terminach bardziej fundamentalnych pojęć czasu i przestrzeni. Jest ona dedukcyjnym wnioskiem uzyskanym ze zbioru tez (1), (2) i (3). Jednak jeśli inaczej niż dotychczas zinterpretujemy przesłanki i ich wzajemny związek logiczny, możemy odczytać metafizykę Witkiewicza na sposób niesubstancjalny i relacjonistyczny. Chciałbym zaproponować takie właśnie odczytanie.

O ile w standardowym modelu interpretacyjnym wniosek jest apodyktycznym sądem uzyskanym jako konsekwencja jego przesłanek, o tyle w prezentowanej tu alternatywnej interpretacji wniosek jest jedynie hipotetycznym wyjaśnieniem stanów rzeczy stwierdzonych w przesłankach. Takie rozumowanie nosi nazwę wnioskowania abdukcyjnego lub inferencji do najlepszego wyjaśnienia. Wnioskując abdukcyjnie, możemy wyprowadzić z koniunkcji odpowiednio zmodyfikowanych tez $(1),\left(4^{*}\right)$ tezę $\left(3^{*}\right)$. Uzyskujemy wtedy następujące rozumowanie:

(1) Tym, co istnieje, są indywidua.

$\left(4^{*}\right)$ Każde indywiduum jest czasowo-przestrzenne.

$\left(3^{*}\right)$ Forma istnienia jest czasowo-przestrzenna.

Omówienia wymagają dwie przesłanki powyższego rozumowania. Wychodząc od drugiej z nich, zaznaczmy, że teza $\left(4^{*}\right)$ jest niekontrowersyjnym wyrazem poglądów Witkiewicza na naturę indywiduum ${ }^{23}$. Zauważmy, że w przeciwieństwie do tezy (4), która przyjmuje status wniosku w interpretacji absolutystycznej, odpowiadająca jej, aczkolwiek nierównoważna z nią teza $\left(4^{*}\right)$ pełni w nowej interpretacji rolę przesłanki. Interpretacja tezy $\left(4^{*}\right)$ jako przesłanki znajduje mocne oparcie w pismach Witkiewicza. Istnienie czasowo-przestrzennej, zróżnicowanej jakościowo rzeczywistości jest jego zdaniem pierwotną i niezaprzeczalną daną doświadczenia ${ }^{24}$, a ogólne stwierdzenia charakteryzujące istnienie zostają przez Witkiewicza przyjęte jako generalizacje z doświadczenia; ich uzasadnienie jest empiryczne, nie zaś inferencyjne.

${ }^{23}$ „Istnienie w całości składa się tylko i jedynie z Istnień Poszczególnych” (tamże, 170); „,istotną właściwością każdego istnienia” jest „czasowość i przestrzenność” (tamże, 193).

24 Tamże, 163. 
Przesłanka (1) jest natomiast jedną z podstawowych tez systemu Witkiewicza i znajduje zastosowanie $\mathrm{w}$ obu interpretacjach. Warto więc spróbować zrekonstruować jej uzasadnienie zaproponowane przez Witkiewicza. Argument wychodzi od założenia o istnieniu świata i angażuje pojęcie Nicości Absolutnej - absolutnego niebytu, „nieistnienia w ogóle niczego" ${ }^{\prime 25}$. Rozumowanie Witkiewicza jest niestety bardzo szkicowe. Chciałbym zaproponować dwie jego rekonstrukcje.

Pierwsza wykorzystuje pojęcia kryterium identyczności wprowadzone do ontologii przez Fregego ${ }^{26}$. Wbrew intuicjom związanym ze słowem „kryterium” nie jest ono epistemicznym warunkiem identyfikacji, dzięki któremu możemy rozpoznać, czy dany obiekt jest identyczny $\mathrm{z}$ innym. Kryterium identyczności jest raczej metafizycznym warunkiem konstytutywnym, określającym, na czym polega bycie egzemplarzem danego rodzaju ${ }^{27}$, determinującym, czy pewien obiekt istniejący $\mathrm{w}$ danym momencie jest tożsamy $z$ obiektem istniejącym $w$ innym momencie. Omawiane kryterium wiąże się z głoszonymi przez Fregego poglądami na istnienie. Według niego istnienie nie jest własnością przedmiotów, ale własnością pojęć, tj. własnością drugiego rzędu. Zdanie egzystencjalne typu „Istnieją P-ty” powinno być rozumiane jako teza dotycząca liczności egzemplifikacji pojęcia P. Jest ono równoważne ze zdaniem: „pojęcie P jest egzemplifikowane (co najmniej) raz". Innymi słowy, zdanie egzystencjalne o obiektach danego rodzaju (podpadających pod dane pojęcie) jest równoważne ze zdaniem stwierdzającym niezerową liczność klasy desygnatów danego pojęcia. Jednak aby zdanie o liczności klasy desygnatów pojęcia było prawdziwe, liczność tej klasy musi być określona. Musi zatem istnieć ontologiczne kryterium identyczności dla obiektów danego rodzaju. Określając, czy dwa obiekty danego rodzaju są tym samym obiektem, czy nie, kryterium identyczności determinuje liczność klasy obiektów danego rodzaju. W sytuacji, gdy kryteria nie są określone, liczność nie jest określona. Natomiast kiedy liczność nie jest określona, istnienie obiektów danego rodzaju także nie jest określone. Dzięki temu możliwe jest ujęcie nicości absolutnej jako stanu, w którym nie ma żadnych określonych kryteriów tożsamości. Istotna z naszej perspektywy jest następująca konsekwencja postulatu Fregego: jeśli liczność klasy egzemplifikacji jest nieokreślona dla dowolnego rodzaju, to nie istnieją obiekty żadnego rodzaju; nie istnieje nic. Mamy zatem do czynienia z nicością absolutną.

25 Tamże, 162.

26 Gottlob Frege, Die Grundlagen der Arithmetik. Eine logisch-mathematische Untersuchung über den Begriff der Zahl (Hamburg: Felix Meiner Verlag, 1986); tłum. ang.: The Foundation of Arithmetic, przeł. John Langshaw Austin (Oxford: Blackwell, 1950).

27 David Wiggins, Samness and Substance (Harvard: Harvard University Press, 1980), 53. 
Rozumowanie Witkiewicza można teraz przedstawić w następujący sposób. Nie wprost przyjmuje on brak wszelkich kryteriów tożsamości: „nic od niczego się nie odróżnia”"28. Zgodnie z tym, co powiedzieliśmy wyżej, pozbawienie świata wielości dobrze określonych kryteriów tożsamości prowadzi do absolutnej nicości. Jednocześnie jednak, skoro nic od niczego się nie odróżnia, wszystko jest tym samym, absolutnym, nieograniczonym jednym. Zdaje się więc, że stan nicości absolutnej jest również stanem, w którym ,jeden z elementów istnienia jest nieograniczony"29.

Zauważmy, że Witkiewicz uznaje, iż zdanie „mogłoby nie istnieć nic" daje się zrozumieć tylko jako wyrażające sąd, że mogłoby nie istnieć nic takiego-a-takiego rodzaju ${ }^{30}$. Do nicości absolutnej zbliżamy się aproksymacyjnie, uzmienniając rodzaj przedmiotów. Stan absolutnej nicości jest jednak nieosiągalny z powodu niemożliwości wyeliminowania nas samych, jako dokonujących tej operacji. O ile jesteśmy w stanie wyobrazić sobie sytuację, w której kryteria tożsamości dla większości rodzajów przedmiotów są nieustalone, co skutkuje tym, że liczność ich zakresów jest nieustalona i obiekty tych rodzajów nie istnieja to tożsamość indywiduum określona jest zawsze. Zawsze bowiem prezentuje się ono, samo dla siebie, jako jedno, odróżniające się od innych, unikalne ja. Nawet jeśli jego warunki tożsamości są dlań epistemicznie niedostępne, są one zawsze określone ontologicznie.

Druga rekonstrukcja wykorzystuje rzadko poruszany element modalny zawarty w pojęciu istnienia: jeśli coś istnieje, to może zostać znalezione i wskazane. Obserwację tę wspiera następująca intuicja, mianowicie: jeśli coś istnieje, to jest obecne $\mathrm{w}$ świecie. A jeśli jest obecne, to daje się wskazaćc ${ }^{31}$. Rozumując przez kontrapozycję: jeśli nie można czegoś wskazać, to znaczy, że nie istnieje. Jeżeli nic nie można wskazać, to znaczy to, że „nie istnieje w ogóle nic”, a stan taki to właśnie nicość absolutna ${ }^{32}$. Rozumowanie Witkiewicza można teraz przedstawić w następujący sposób. Przyjmuje się nie wprost hipotezę, że „jeden z elementów istnienia jest nieograniczony" ${ }^{\prime 3}$, i wywodzi na mocy tego założenia, że nie ma innych elementów, "jest tylko ten jeden jedyny element" ${ }^{34}$. Jednak już Melissos konkludował, że tak pomyślane jedno jest z konieczności absolutnie jednorodne, ponieważ jakiekolwiek zróżnicowanie natychmiast

28 Witkiewicz, „Pojęcia i twierdzenia”, 165.

29 Tamże, 169.

30 Tamże, 162.

31 Por. słynne „nie znał byś tego, co nie jest (to przecież niemożliwe), ani byś nie wskazał” z fragmentu 2. Parmenidesa (Parmenides D-K 28 B2, cyt. za: Geoffrey Stephen. Kirk i in., Filozofia przedsokratejska (Warszawa: PWN, 1999), 246.

32 Por. Witkiewicz, „Pojęcia i twierdzenia”, 165-167.

33 Tamże, 169.

34 Tamże. 
pociąga wielość i zaprzecza pierwotnemu założeniu o absolutnej jedności ${ }^{35}$. Dlatego element ten musi być absolutnie jednorodny, wszędzie taki sam, tak jak byt Parmenidesa, który „nie jest takim, aby miał być tu bardziej, a tam mniej [...] sobie wszak zewsząd jest równy" ${ }^{\prime 36}$. W ramach tak pojętej jedności nie da się wskazać czegokolwiek. Na mocy wcześniejszej uwagi stan taki jest tożsamy ze stanem absolutnej nicości.

Przedstawione rozumowania każą utożsamiać stan opisywany tezą monizmu egzystencjalnego z nicością absolutną. Jednak Witkiewicz był przekonany, że nasze najbardziej pierwotne i elementarne doznania zaznajamiają nas z wielością. Dlatego pozytywne istnienie absolutnej nicości uznawał za sprzeczne ze świadectwami i niepojmowalne. W konsekwencji Witkiewicz odrzucał hipotezę monistyczną, przyjmując w zamian tezę pluralizmu i postulował istnienie wielości „elementów istnienia" - istnień poszczególnych, indywiduów ${ }^{37}$.

Po prezentacji przesłanek możemy przejść do wyjaśnienia statusu tezy, że forma istnienia jest czasowo-przestrzenna - wniosku $\left(3^{*}\right)$. W tej interpretacji teza $\left(3^{*}\right)$ jest wynikiem abdukcyjnej inferencji do najlepszego wyjaśnienia zjawiska powszechnej, czasowo-przestrzennej organizacji istnienia. Witkiewicz zaznacza, że to właśnie skończoność indywiduów „implikuje pojęcie jednej jedynej Formy Istnienia" ${ }^{38}$. W tej interpretacji przyjmuję, że Witkiewicz wprowadził kategorię formy istnienia dla potrzeb wysłowienia formalnej jedności dziedziny ontologicznej. W myśl proponowanej tu interpretacji pojęcie takiej zasady formalnej daje się uzasadnić następującym rozumowaniem.

Zgodnie z uzasadnieniem tezy (1) musimy „przyjąć wielość Istnień Poszczególnych"39. Całość tego, co istnieje, składa się więc z mnogości indywidualnych osobników. Jednak każdy osobnik o tyle sam jest

35 David Sedley, „Parmenides and Melissus”, w: The Cambridge Companion to Early Greek Philosophy, red. Anthony Arthur Long (Cambridge: CUP, 1999), 127.

36 Parmenides, D-K 28 B 8, cyt. za: Giovanni Reale, Historia filozofii starożytnej, t. 1: Od początków do Sokratesa, (Lublin: RWKUL, 1993), 144.

37 Witkiewicz nazywa ją pierwszą implikacja metafizyczną: „Pojęcie Istnienia implikuje pojęcie Wielości” (Witkiewicz, „Pojęcia i twierdzenia”, 160).

38 Tamże, 182. Sposób rozumienia przez Witkiewicza relacji implikacji nie jest jasny. Jej zastosowanie pokazuje, że nie była to implikacja materialna ani tym bardziej wynikanie logiczne. Witkiewicz przyznaje, że implikację rozumie „materialnie” - treściowo - tj. tak, że „przyjęcie konieczne istnienia a zmusza mnie do przyjęcia istnienia b" (tamże, 416), jednak Dombrowski uważa, że Witkiewiczowska implikacja jest rozumowaniem przeciwnym do dedukcji i odpowiada relacji entailment - „bycia pociąganym przez" (Maciej Dombrowski, Filozofia i nauka: trudne zwiazki (Toruń: Wydawnictwo Naukowe UMK, 2011), 153). Charakter tej „relacji pociągania”, jaki przejawia się w jej zastosowaniu w tekście, wskazuje na to, że bardzo często występuje ona $\mathrm{w}$ rozumowaniach abdukcyjnych, czyli rozumowaniach do najbardziej prawdopodobnego wyjaśnienia.

39 Witkiewicz, „Pojęcia i twierdzenia”, 169. 
wyróżnionym indywiduum, o ile nie jest identyczny z którymś z pozostałych indywiduów, a więc o ile różni się od wszystkich pozostałych indywiduów. Jednocześnie jednak wszystkie indywidua, o ile mają tworzyć jedność wyższego rzędu - całość istnienia - muszą być wzajemnie analogiczne pod pewnym bardzo ogólnym względem: „wielość musi być jednościa, aby tę wielość stanowić" ${ }^{40}$, „inaczej nie mielibyśmy do czynienia z Wielością jako taką, tylko z poszczególnymi jej elementami, z których każdy byłby jednością"41. Można więc założyć, że Witkiewicz wprowadza kategorię formy istnienia właśnie w celu wyrażenia formalnej jedności elementów istnienia.

Teza $\left(3^{*}\right)$ nie tylko stanowi wyjaśnienie dla powszechnie obserwowalnej formalnej jedności istnienia, ale pozwala pomyśleć dowolną wielość indywiduów jako jedność, przede wszystkim wtedy, kiedy rozważamy istnienie w całym jego zakresie, jako nieskończone. Z oczywistych względów nie może być percepcyjnie reprezentowane i „dopiero jako objęte jedną dwoistą tożsamą ze sobą czasowo-przestrzenną formą musimy uznać Istnienie w całości za jedyne i tożsame ze sobą w swej wielości" ${ }^{42}$.

Z perspektywy tych rozważań najbardziej istotnym zagadnieniem związanym z pojęciem formy istnienia jest status ontologiczny formy. Rola tego pojęcia w proponowanej rekonstrukcji nie determinuje jego absolutystycznej interpretacji. Formę można bowiem rozumieć jako schemat lub zasadę rządzące tym, jak szeroko rozumiane obiekty wchodzą w relacje ze sobą. Determinują one sposób, w jaki byty nie-fundamentalne nadbudowują się lub są ugruntowane w podstawowej warstwie ontologicznej. Witkiewicz uważał, że takie zasady nie mogą istnieć poza bytami, w których dochodzą do bytu: „,są wtopione jako prawidłowość w dany przebieg" i nie są „czymś odrębnym"43.

Proponowana interpretacja pozwala także zrozumieć te fragmenty pism Witkiewicza, które wykluczają absolutystyczną interpretację formy. Wskażmy choćby postulat, że forma istnienia „istnieje [...] razem $z$ Istnieniem $i$ tak jak Istnienie bez tej formy, tak samo ta forma bez Istnienia jest niewyobrażalna" ${ }^{44}$. Teza ta jest bardzo ważna dla omawianego zagadnienia. Wraz z tezą (1) pozwala bowiem uzasadnić hipotezę,

40 Tamże, 175.

41 Tamże, 177.

42 Tamże, 181.

43 Witkiewicz, "Spór o monadyzm”, 109. Waga tej tezy dla teorii Witkiewicza uwidacznia się w sporze z Janem Leszczyńskim. Kiedy Leszczyński zarzuca Witkiewiczowi, że jego teoria jest „niepojęta fantasmagorią”, która „przestrzeń sama wspiera koloniami monad” (Witkiewicz, „,Spór o monadyzm”, 77), Witkiewicz ripostuje, że wcale jej nie "podpiera monadami - ona stanowi jedność z bytem w całości - pusta jest nie-do-przyjęcia" (tamże, 115).

44 Witkiewicz, „Pojęcia i twierdzenia”, 176. 
że status ontyczny czasu i przestrzeni jest pochodny i zależny od indywiduów. Zgodnie z (1) tym, co istnieje, są indywidua; zgodnie zaś $\mathrm{z}$ powyższa tezą forma istnienia jest niemożliwa ${ }^{45}$ bez istnienia. $W$ konsekwencji czas i przestrzeń stanowiące „dwie strony dwoistości jednej dwoistej Formy istnienia" są niemożliwe bez indywiduów, a zatem zależą od nich i w tym sensie są na nich ufundowane.

Prezentowaną interpretację relacjonistyczną wspierają nie tylko świadectwa inferencyjne. Witkiewicz $\mathrm{w}$ wielu miejscach swojego traktatu udziela bezpośredniego wsparcia tezie o niesubstancjalnym charakterze czasu i przestrzeni ${ }^{46}$.

Na zakończenie tej sekcji zauważmy, że różnice między dwiema interpretacjami można wyrazić, posługując się zaczerpniętym od Willarda Van Ormana Quine'a rozróżnieniem ontologii i ideologii ${ }^{47}$. Możemy powiedzieć, że pierwsza $\mathrm{z}$ interpretacji włącza pojęcie formy w zakres zmienności zmiennych teorii i tym samym zobowiązuje się ontologicznie do istnienia konkretnego desygnatu pojęcia formy istnienia - czyli

45 Przy założeniu, że wyobrażalność rozumiemy jako pojmowalność i akceptujemy, że pojmowalność pociąga możliwość.

46 Witkiewicz posługuje się nazwami Czasu Całości Istnienia; alternatywnie stosuje również termin „Rzeczywisty Czas Całości Istnienia” oraz „Czas Abstrakcyjny”. Pojęcie Czasu Abstrakcyjnego zakopiańczyk zalicza do pojęć „abstrakcyjnych pochodnych [...], które tworzymy jako uogólnienia z pojęć odpowiadających istnościom rzeczywistym (konkretom - autor)” (Witkiewicz, „Pojęcia i twierdzenia”, 308). „Czas jest pojęciem abstrakcyjnym, w tym znaczeniu, że nie odpowiada mu żadna rzeczywistość w rodzaju Istnienia w całości, (IP), (AT) i (AR)” (tamże, 188). "Jest ono tylko i jedynie koniecznym pojęciem” (tamże, 188), które oznacza „nieskończone, czyli wieczne trwanie Istnienia w całości, mimo ograniczoności (ATN) mających swój początek i koniec" (tamże, 187-188). Abstrahując od wewnętrznego trwania konkretnych indywiduów, „,dostajemy pojęcie abstrakcyjne, któremu nie odpowiada nic rzeczywistego. [...] Rzeczywisty Czas Istnienia w całości jest kompletną fikcją o której nic powiedzieć nie można [...] (tamże, 192). Czas Całości Istnienia jest „absolutnie względny i niewymierzalny" (tamże, 204). Z tego powodu nie może być utożsamiany z pojęciem czasu fizycznego. Ten ostatni jest oczywiście mierzalny i jego upływ jest równomierny lub nierównomierny, w zależności od szybkości zmiany danych w obserwowanym układzie, w stosunku do założonego układu odniesienia (zob. tamże, 188). Według Witkacego ontologia czasu fizycznego jest metafizycznie irrelewantna, gdyż jest budowana w uzależnieniu od celów eksplanacyjnych określonej teorii fizycznej. Zależnie od potrzeb fizycy mogą przyjmować zarówno interpretacje absolutystyczne, jak i relacjonistyczne (tamże, 334). Rozumienie czasu jako abstrakcji wyklucza interpretację absolutystyczna, ponieważ jako abstrakt czas jest jednak zależny, a więc nie absolutny. Zależność można rozumieć dwojako: jako zależność ontologiczną od konkretów i epistemiczną od procedur abstrakcji. Ze względu na utożsamienie czasu i przestrzeni jako dwóch stron jednej dwoistej formy istnienia to samo można przenieść mutatis mutandis na rozumienie przestrzeni, niemniej inne fragmenty przydają przestrzeni pewnej realności, wynikłej z rozciągłości indywiduów, której czas mieć nie może (tamże, 192-193).

47 Willard V. O. Quine, „Ontology and ideology”, Philosophical Studies, 2(1) (1951). 
czasu i przestrzeni (czaso-przestrzeni). Druga interpretacja traktuje to pojęcie jako wyrażalne $\mathrm{w}$ języku teorii, ale nie włączania go $\mathrm{w}$ zakres kwantyfikacji egzystencjalnej. Różnicę dobrze ukazuje następująca uwaga: „teoria może być ideologicznie zobowiązana do pojęć relacyjnych, które nadają strukturę bytom postulowanym przez daną teorię, bez jednoczesnego postulowania nowego rodzaju bytów" ${ }^{\prime \prime 8}$.

\section{Relacjonizm vs absolutyzm a monizm vs pluralizm}

Dotychczas przedstawiłem dwie interpretacje Witkiewiczowskiej metafizyki czasu i przestrzeni. Pierwsza z nich postuluje absolutne i niezależne od indywiduów istnienie przestrzeni jako całości. Czas i przestrzeń (czaso-przestrzeń) są pierwotne ontologicznie. Indywidua uznaje się za wyróżnione części tej pierwotnej całości (jej „rzeczywiste ograniczenia"). Druga interpretacja uznaje indywidualne osobniki za ontologicznie pierwotne. Nieskończona mnogość indywiduów konstytuuje czas i przestrzeń jako całość. „Rzeczywiste ograniczenia” formy istnienia to rozciągłe indywidua uporządkowane $\mathrm{w}$ sposób synchroniczny i diachroniczny. Forma istnienia jest porządkiem ich występowania, a czaso-przestrzeń jest całością powstałą w wyniku ich wzajemnych powiązań.

Wyróżnione stanowiska można także powiązać z ogólną dystynkcją filozoficzną między monizmem i pluralizmem. Te dwa ostatnie terminy odnoszę do siatki pojęciowej zaproponowanej przez Jonathana Schaffera ${ }^{49}$. Autor ten wprowadza rozróżnienie na monizm egzystencjalny i monizm podstaw ontologicznych ${ }^{50} \mathrm{z}$ jednej strony oraz na pluralizm podstaw ontologicznych i pluralizm egzystencjalny ${ }^{51} \mathrm{z}$ drugiej. Monizm egzystencjalny postuluje, że istnieje tylko jeden konkret. To pojęcie monizmu nie przyda się w obecnych rozważaniach, ponieważ obie wcześniej wyróżnione interpretacje akceptują kluczową dla Witkiewicza tezę pluralizmu egzystencjalnego. Zasadnicze znaczenie ma natomiast teza monizmu podstaw ontologicznych, która stwierdza, że tylko jeden konkretny obiekt jest ontologicznie pierwotny i jest nim całość tego, co istnieje. Całość stanowi więc fundament bytowy jej części. Poglądem przeciwstawnym jest pluralizm podstaw ontologicznych, zgodnie z którym pierwotna ontologicznie jest mnogość konkretów. Całość jest więc

48 Phillip Bricker, „Ontological Commitment”, w: The Stanford Encyclopedia of Philosophy, red. Edward N. Zalta, (https://plato.stanford.edu/entries/ontological-commitment/, dostęp: 25.08.2018).

49 Jonathan Schaffer, "Monism: The priority of the whole”, Philosophical Review, 119 (1) (2010); Jonathan Schaffer, „Monism”, w: The Stanford Encyclopedia of Philosophy, (https://plato.stanford.edu/entries/monism/dostęp: 25.08.2018).

${ }_{50}$ Shaffer, "Monism”.

51 Tamże. 
zależna bytowo od jej części. W dalszej części pracy, używając terminów monizmu i pluralizmu, będę odnosił się wyłącznie do stanowisk w kwestii podstaw ontologicznych.

Zaproponowana siatka pojęciowa angażuje pojęcie bytu pierwotnego ontologicznie lub fundamentu bytowego. Jej zastosowanie daje się uzasadnić wspólnym dla obu autorów zainteresowaniem zagadnieniem fundamentu ontologicznego rzeczywistości ${ }^{52}$. W przypadku obu filozofów to, co fundamentalne, rozumiane jest jako bytowo pierwotne, podstawowe lub $\mathrm{w}$ tym sensie ostateczne i nieredukowalne ${ }^{53}$. Pierwotność bytową możemy także pojmować jako niezależność ontologiczną ${ }^{54}$. Dany byt jest niezależny ontologicznie, kiedy nie wymaga istnienia żadnego innego bytu; przeciwnie, spośród dwu bytów x i y, jeśli x jest ontologicznie zależny od $\mathrm{y}$, to wymaga on istnienia $\mathrm{y}$, co z kolei można rozumieć tak, iż nie jest możliwe, że przyjmuje się x i nie przyjmuje $\mathrm{y}^{55}$. Współcześnie uznaje się, że relacja bytowej zależności jest asymetrycz$\mathrm{na}^{56}$, tj. dla dowolnych obiektów $\mathrm{x}$, y spełniona jest teza: jeśli $\mathrm{x}$ jest zależny od $y$, to $y$ nie jest zależny od $x$. Inaczej oba obiekty zależałby od siebie nawzajem, co z kolei zaprzecza podstawowym intuicjom związanym z pojęciem bytowej pierwotności. Z tego względu przyjmuję, że relacja ta jest asymetryczna.

W kontekście przyjętej siatki pojęciowej monizm można rozumieć jako tezę stwierdzająca, że istnieje tylko jeden byt pierwotny; odpowiednio pluralizm jako tezę stwierdzająca, że istnieje więcej niż jeden byt pierwotny. Tezie monizmu w ramach filozofii Witkiewicza odpowiadałoby przekonanie, że całość czaso-przestrzeni jest pierwotnym konkretem, niezależnym od indywiduów. Tezie pluralizmu zaś odpowiadałby pogląd przeciwny, mianowicie, że czaso-przestrzeń nie jest pierwotnym ontologicznie konkretem. Dla przejrzystości tezy monizmu i plu-

52 "Cielesna monada jest czymś pierwotnym; przyjmuję ten element za pierwotny (a jakiś muszę), przy pomocy którego inne mogę opisać i doń sprowadzić" (Stanisław Ignacy Witkiewicz, Roman Ingarden, Korespondencja filozoficzna, red. Bohdan Michalski (Warszawa: IFiS PAN, 2002), 62. Ponadto zob. Stanisław Ignacy Witkiewicz, „NNauki ścisłe a filozofia", w: Stanisław Ignacy Witkiewicz, Dzieła zebrane, t. 15, red. Maciej Dombrowski, Magdalena Bizior-Dombrowska (Warszawa: PIW, 2014), 83-84, oraz: Witkiewicz, "Spór o monadyzm”, 186; Jonathan Schaffer, „On What Grounds What", w: Metametaphysics, red. David Chalmers, David Manley, Ryan Wasserman (Oxford: OUP, 2009), 347; Shaffer, „Monism”, 36.

53 Jonathan Schaffer, "Spacetime the one substance", Philosophical Studies 145 (1) (2009).

54 Ross Paul Cameron, „Turtles all the way down: regress, priority and fundamentality", The Philosophical Quarterly 58 (230) (2008): 3-4.

55 Zob. Kit Fine, „The Study of Ontology, Noûs 25 (3) (1991): 269-270.

56 Jonathan Schaffer, „Is There a Fundamental Level?”, Noûs 37 (3) (2003). Por. prace różnych autorów zebrane w tomie: Metaphysical Grounding, red. Fabrice Correia, Benjamin Schneider (Cambridge: CUP, 2012). 
ralizmu $\mathrm{w}$ odniesieniu do Witkiewicza możemy wrazić następująco: (W-monizm) czaso-przestrzeń jest pierwotna ontologicznie; (W-pluralizm) czaso-przestrzeń nie jest pierwotna ontologicznie.

Można teraz zadać pytanie o związek stanowisk monizmu (pluralizmu) i absolutyzmu (relacjonizmu). W odpowiedzi będę argumentował, że absolutyzm prowadzi do sprzeczności zarówno przy założeniu W-monizmu, jak i W-pluralizmu. Argument przyjmuje następująca postać:

1) Absolutyzm jest prawdziwy.

2) Jeśli (1), to czaso-przestrzeń nie jest zależna bytowo od tego, co istnieje.

3) Czaso-przestrzeń nie jest zależna bytowo od tego, co istnieje.

4) Istnieje wielość indywiduów.

5) Czaso-przestrzeń nie jest zależna bytowo od indywiduów.

6) W-monizm jest prawdziwy.

7) Jeśli (6), to czaso-przestrzeń jest pierwotna bytowo.

8) Czaso-przestrzeń jest pierwotna bytowo.

9) Obiekt pierwotny bytowo nie jest jednorodny.

10) Czaso-przestrzeń nie jest jednorodna.

Zależności logiczne w obrębie argumentu wyglądają następująco. Przesłanka (1) jest założeniem absolutyzmu. Teza (2) wynika na mocy definicji z (1), a (3) z koniunkcji tez (2) i (1). Teza (4) jest jedną z podstawowych tez metafizyki Witkiewicza ${ }^{57}$. Teza (5) wynika z tez (3) i (4); (6) jest założeniem dla potrzeb argumentu, a (7) jest konsekwencją definicyjną założenia (6). Z obu tych tez uzyskujemy wniosek (8). Tezę (9) uzyskujemy na mocy argumentu z nicości absolutnej Witkiewicza ${ }^{58}$, konsekwencją zaś tez (8) i (9) jest teza (10).

(10) stwierdza niejednorodność czaso-przestrzeni. Należy więc rozumieć, że czaso-przestrzeń jest w jakiś sposób zróżnicowana, heterogeniczna. Jej rejony nie są wzajem identyczne, tj. różnią się między sobą. Jednak akceptując tezę absolutyzmu, trudno wyjaśnić heterogeniczność przestrzeni. Skoro jest bytowo niezależna, jej własności nie powinny zależeć od czegokolwiek. Jednak wtedy nie potrafimy wyjaśnić ani samego faktu zróżnicowania, ani jego charakteru (takiego, a nie innego zróżnicowania).

Można co prawda argumentować, że poszczególne regiony różnią się ze względu na relacje zewnętrzne, w które wchodzą. Jednak relacje te wymagają dobrze określonych wyróżnionych regionów jako relatów. Jeśli zaś ich relata są dobrze wyróżnionymi regionami, to znaczy, że musiały być one wyróżnione, zanim weszły w różnicujące je relacje. Taki

57 Witkiewicz, „Pojęcia i twierdzenia”, 175.

58 Por. rozważania w paragrafie 3. 
stan rzeczy jest oczywiście sprzeczny. Witkiewicz nie podejmuje tego kierunku argumentacji.

Zamiast tego rozważa inną możliwość. Wcześniej zauważyliśmy, że Witkiewicz postrzegał Istnienia Poszczególne - indywidua - jako wyróżnioną klasę podziałów czaso-przestrzeni (realne ograniczenia). Utożsamiał realne ograniczania przestrzeni z Istnieniami Poszczególnymi. Każde zaś Istnienie Poszczególne - indywiduum - jako tożsame odróżnia się od pozostałych. Każde jest unikalne i dlatego regiony mogą być wyróżnione ze względu na istnienia poszczególne. Sądzę, że tak należy rozumieć sformułowania mówiące o tym, że każde indywiduum jest ograniczaniem realnym czaso-przestrzeni. Argumentowałem, że są one częściami wyróżnionymi przez fakt, że to one właśnie są pierwotne ontycznie względem dowolnych całości, które mogą powstawać przez ich agregację. Są także pierwotne względem zupełnej całości czaso-przestrzeni (formy istnienia), którą Witkiewicz utożsamiał z istnieniem ${ }^{59}$. To jednak oznacza, że czaso-przestrzeń jest zależna od wszystkich istnień indywidualnych, co wyraża teza (11).

11) Jeśli (10), to czaso-przestrzeń jest zależna bytowo od indywiduów.

12) Czaso-przestrzeń jest zależna bytowo od indywiduów.

Teza (12) wynika zaś z tez (10) i (11) i jest sprzeczna z tezą (5). Kluczowe założenia tego argumentu to tezy absolutyzmu (1) i W-monizmu (6) oraz hipoteza Witkiewicza dotycząca stosunku istnienia do formy istnienia uzasadniająca tezę (11). Jedną z tych tez należy więc odrzucić, aby uniknąć wywiedzionej sprzeczności. Teza (11) znajduje oparcie w pismach Witkiewicza i jest trudna do odrzucenia. $Z$ tego względu naturalnym dla absolutysty posunięciem jest odrzucenie tezy (6). Zauważmy jednak, że odrzucając W-monizm, absolutysta musi przyjąć W-pluralizm; jako warianty monizmu i pluralizmu stanowiska te są łącznie wyczerpujące i wzajemnie wykluczające. Jeśli jednak przyjmiemy W-pluralizm, to możliwa jest następująca argumentacja:

13) W-pluralizm jest prawdziwy.

14) Jeśli (13), to czaso-przestrzeń nie jest pierwotna bytowo.

15) Czaso-przestrzeń nie jest pierwotna bytowo.

16) Jeśli (15), to czaso-przestrzeń jest zależna bytowo.

Rozumowanie rozpoczynamy od założenia tezy (13). Teza (14) jest jej rozwinięciem definicyjnym. Teza (15) wynika z koniunkcji tez (13) i (14),

59 Por. przywoływany wcześniej cytat: „istnieje [...] razem z Istnieniem i tak jak Istnienie bez tej formy, tak samo ta forma bez Istnienia jest niewyobrażalna" (Witkiewicz, „Pojęcia i twierdzenia”, 176). 
natomiast teza (16) wynika z poprzedniej i definicji pierwotności bytowej. Teza (16) wyraźnie przeczy intuicjom związanym z absolutyzmem, absolutysta mógłby jednak argumentować, że (16) nie przeczy samej tezie absolutyzmu. To zaś dlatego, że absolutyzm stwierdza jedynie, że czaso-przestrzeń nie jest zależna bytowo od tego, co istnieje, niemniej może być zależna bytowo. Jeśli tak, to od czego? Jak argumentowałem poprzednio, Witkiewicz opowiada się za hipoteza, że czaso-przestrzeń zależy bytowo od całości zindywidualizowanego, kolektywnie rozumianego istnienia. To jednak oznacza, że zgodnie z tezami (2) i (3) oraz schematem modus tollens dochodzimy do negacji absolutyzmu.

Okazuje się więc, że aby uniknąć sprzeczności, absolutysta musi odrzucić nie tylko W-monizm (6), ale także uzasadnienie tezy (11). W rezultacie nakłada na siebie obligację do alternatywnego wyjaśnienia tezy Witkiewicza o tożsamości formy $\mathrm{i}$ istnienia w taki sposób, aby nie prowadziła ona do sprzeczności z tezą absolutyzmu.

Podsumowując powyższy ciąg rozumowań, należy zauważyć, że absolutyzm $\mathrm{w}$ połączeniu z podstawowymi tezami Witkiewicza prowadzi do sprzeczności bez względu na to, czy przyjmiemy W-monizm, czy W-pluralizm jako stanowisko w kwestii podstaw bytowych. Powyższy argument zdaje się trudny do odparcia dla filozofa dokonującego interpretacji ontologii autora Nienasycenia, gdyż opiera się na twierdzeniach stanowiących zrąb ontologii Witkiewicza. Nie znaczy to jednak, że stanowiska absolutystycznego nie można bronić.

W literaturze przedmiotu można znaleźć interesujący argument wysuwany przez badaczy, którzy starają się łączyć absolutyzm z relacjonizmem, zgadzając się, że w teorii Witkiewicza „przestrzeń relacyjna stanowi abstrakcję od »rozciągłości« monad (rozciągłości zdarzeń), lecz jednocześnie konkretne monady znajdują się w absolutnej przestrze$\mathrm{ni}^{\prime \prime 60}$. Dla poparcia tego stanowiska argumentuje się, że przyjmując relacjonizm, a więc tezę, ze przestrzeń jest strukturą relacji między rozciągłymi monadami, należy również przyjąć uprzednie istnienie monad wchodzących $w$ te relacje. Jednak owe monady, jako rozciągłe, muszą gdzieś istnieć. Wywodzi się zatem, że istnieją w jakiejś uprzedniej przestrzeni, tym razem już absolutnej ${ }^{61}$.

Wydaje się jednak, że wniosek stwierdzający absolutność przestrzeni jest przedwczesny, a sam argument daje się odeprzeć. Można bowiem zapytać po raz kolejny, czy ów ośrodek, w którym istnieją monady wchodzące w swego rodzaju związki przestrzenne, sam jest $\mathrm{z}$ konieczności absolutny. Gdyby był z konieczności absolutny, to przestrzeń byłaby absolutna. Jednak nie jest konieczne, że jest absolutny, ponieważ jest możliwe, że istnieje w rezultacie powiązań "przestrzennych" między

${ }^{60}$ Kościuszko, „Witkacy uwikłany”, 333.

61 Tamże, 334. 
obiektami (monadami) niższego rzędu wielkości. Jeśli tak, to ów ośrodek nie jest absolutny. Sceptyk może jednak pytać nadal, czy ów nieabsolutny ośrodek monad niższego rzędu nie jest przypadkiem zależny od monad jeszcze niższego rzędu, które wszak już wypełniają ośrodek absolutny, który w takim razie byłby tym, co nazywamy przestrzenią absolutną. Oczywiście rozumowanie przebiega ad infinitum i zaprzecza tezie, iż „pojęcie przestrzeni absolutnej miałoby być pojęciem pierwotnym w stosunku do pojęcia przestrzeni relacyjnej" ${ }^{\prime \prime 2}$.

Powyższy argument wymaga istotnego założenia dotyczącego struktury bytu indywidualnego. Mianowicie obowiązuje on jedynie pod warunkiem, że przyjmuje się nieskończoną hierarchię monad. Witkiewicz oczywiście przyjmował tę kluczową hipotezę. W swoim filozoficznym żargonie nazywał ją hipotezą nieskończoności w małości ${ }^{63}$. W stosunku do każdego konkretnego indywiduum - monady - postuluje on jego podział na indywidua częściowe pierwszego rzędu małości w stosunku do danego indywiduum, następnie drugiego rzędu itd. Taka struktura „nie może napotkać ograniczenia, musimy przyjąć w granicy [...] (IPN) nieskończenie małe jako (IPCN) wszystkich (IPN) $=\left(\text { IPCN }_{\infty}\right)^{\prime \prime 64}$. Tak jak całe istnienie składa się z indywiduów, tak i każde indywiduum składa się z nieskończonej ilości mniejszych indywiduów. Podobnie jak istnienie, tak i „Czas i Przestrzeń są nieskończone w wielkości i nieskończenie podzielne, czyli ciągłe" 65 .

Przyjęcie przez Witkiewicza hipotezy, że szereg rzędów wielkości monad, jak „szereg alefów w nieskończoność pełznie”, ma kapitalne znaczenie dla analizowanego zagadnienia. Hipoteza nieskończoności w małości umożliwia na gruncie filozofii Witkiewicza opis czaso-przestrzeni jako nieabsolutnej, tj. zależnej od wielości monad. Dzięki niej prawdziwe jest twierdzenie, że w stosunku do dowolnego szeregu wielkości monad przestrzeń, którą konstytuują owe monady, jest zależna od monad niższego rzędu wielkości. Zarazem bez względu na rząd wielkości monad nie można twierdzić, że są fundamentalne i że jakkolwiek istnieją one w jakimś „przestrzennym” stosunku do siebie, to jednak istnieją także $\mathrm{w}$ jakimś ośrodku od innych monad niezależnym, a więc absolutnym.

62 Tamże.

63 Witkiewicz, „Pojęcia i twierdzenia”, 296; Stanisław Ignacy Witkiewicz, „Nowe formy w malarstwie i wynikające stąd nieporozumienia”, w: Stanisław Ignacy Witkiewicz, Dzieła zebrane, t. 8, red. Janusz Degler, Lech Sokół (Warszawa: PIW, 2002), 10.

64 Witkiewicz, „Pojęcia i twierdzenia”, 248. W sprawie stosowanych skrótów zob. wyżej, przypis 11.

65 Witkiewicz, „Pojęcia i twierdzenia”, 248. 


\section{Zakończenie}

Przedstawiłem dwie interpretacje Witkiewiczowskiej filozofii czasu i przestrzeni - absolutystyczną i relacjonistyczną. Zestawiając oba stanowiska, starałem się pokazać, że absolutyzm prowadzi do sprzeczności zarówno przy założeniu pewnych wariantów monizmu, jak i pluralizmu. Wobec ambiwalencji wielu świadectw tekstualnych uzyskane wyniki nie mogą zostać uznane za wystarczające do ostatecznego rozstrzygnięcia kwestii interpretacji metafizycznego modelu świata zawartego w pisarstwie zakopiańczyka. Pokazują jednak, że absolutystyczna rekonstrukcja metafizyki Witkiewicza być może nie wystarczy, by uspójnić i wyjaśnić wszystkie poglądy metafizyczne Witkacego.

W pracy tej zwróciłem także uwagę na kategorię pierwotności ontologicznej. Witkiewicz uważał, że charakteryzuje ona właśnie Istnienia Poszczególne stanowiące fundament ontologiczny świata opisanego w jego metafizycznej teorii. Przeprowadzone w świetle tej kategorii rozważania eksponują pokrewieństwo ontologicznych dociekań Witkiewicza i współczesnych dyskusji metafizycznych wykorzystujących to właśnie pojęcie. W konsekwencji pokazuja, wbrew niektórym interpretatorom, że filozofia autora Nienasycenia nie jest anachronicznym intelektualnym żartem ${ }^{66}$; wręcz przeciwnie. Fakt, że środki pojęciowe przejęte ze współczesnych debat metafizycznych dostarczają narzędzi jej zrozumienia, uzasadnia wyrażane przez innych autorów przekonanie, że metafizyka Witkiewicza „zawiera wiele problemów dyskutowanych współcześnie" ${ }^{\prime \prime 7}$.

\section{Bibliografia}

Biegalska Agnieszka. 2009. „Filozofia przyrody w recepcji Stanisława Ignacego Witkiewicza. Czas i przestrzeń". Ruch Filozoficzny 3: 429-440.

Bricker Phillip. „Ontological Commitment”. W: The Stanford Encyclopedia of Philosophy, red. Edward N. Zalta (https://plato.stanford.edu/archives/ win2016/entries/ontological-commitment/).

Cameron Ross P. 2008. „Turtles all the way down: regress, priority and fundamentality". The Philosophical Quarterly 58 (230): 3-4.

${ }^{66}$ Józef Tarnowski, „Filozofia Witkacego - intelektualny żart?”, w: Witkacy w Polsce i na świecie, red. M. Skwara, (Szczecin 2001); Józef Tarnowski, „Czy filozofie Witkacego można uratować?", w: Powroty do Witkacego, red. Józef Tarnowski, (Słupsk: Wydawnictwo UG, 2006), 258.

67 Maciej Dombrowski, „Stanisław Ignacy Witkiewicz - filozof "problematyczny «", Kultura i Edukacja, 3/2007, 59. 
Correia Fabrice, Benjamin Schneider (red.). 2012. Metaphysical Grounding. Cambridge: CUP.

Dombrowski Maciej. 2007. „Stanisław Ignacy Witkiewicz - filozof »problematyczny «". Kultura $i$ Edukacja 3: 50-61.

Dombrowski Maciej. 2011. „Filozofia i nauka: trudne związki. Metallmann Witkiewicz - Gawecki". Toruń: Wydawnictwo UMK.

Fine Kit. 1991. „The Study of Ontology”. Noûs 25 (3): 263-294.

Gołosz Jerzy. 2002. „Ruch, przestrzeń, czas”. Filozofia Nauki 10 (1): 7-31.

Kirk Geoffrey S., John E. Raven, Malcolm Schofield. 1999. Filozofia przedsokratejska, przeł. Jacek Lang, Warszawa: PWN.

Kościuszko Krzysztof. 2016. „Witkacy uwikłany w spór między absolutną a relacyjną teorią przestrzeni". Rocznik Podhalański XI: 321-336.

Kotarbiński Tadeusz. 2002. „Witkiewicz Stanisław Ignacy: »Pojęcia i twierdzenia implikowane przez pojęcie Istnienia «", W: Stanisław Ignacy Witkiewicz, Dzieła zebrane. T. 13. Red. Bohdan Michalski, Warszawa: PIW.

Michalski Bohdan. 1979. Polemiki filozoficzne Stanistawa Ignacego Witkiewicza. Warszawa: PIW.

Morganti Matteo. 2015. „Relational Time”. W: Metaphysics in Contemporary Physics, red. Tomasz Bigaj, Christian Wuthrich, Amsterdam: Brill Rodopi.

Reale Giovanni. 1993. Historia filozofii starożytnej. T. 1: Od początków do Sokratesa. Lublin: RW KUL.

Quine Willard V. 1951. „Ontology and ideology”. Philosophical Studies 2 (1): $11-15$.

Schaffer Jonathan. 2003. „Is There a Fundamental Level?”. Noûs 37 (3): 498-517.

Schaffer Jonathan. 2009. „On What Grounds What”. W: Metametaphysics, red. David Chalmers, David Manley, Ryan Wasserman, 347-383. Oxford: OUP.

Schaffer Jonathan. 2009. „Spacetime the one substance”. Philosophical Studies 145 (1): 131-148.

Schaffer Jonathan. 2010. „Monism: The priority of the Whole”. Philosophical Review 119 (1): 31-76.

Schaffer Jonathan. „Monism”. W: The Stanford Encyclopedia of Philosophy, red. Edward N. Zalta. Dostęp 25.08.2018. https://plato.stanford.edu/archives/win2016/entries/monism/.

Sedley David. 1999. „Parmenides and Melissus”. W: The Cambridge Companion to Early Greek Philosophy, red. Anthony Arthur Long, 113-133. Cambridge: CUP.

Soin Maciej. 1995. Filozofia Stanisława Ignacego Witkiewicza. Wrocław: Wydawnictwo Leopoldinum Fundacji dla Uniwersytetu Wrocławskiego.

Tarnowski Józef. 2006. „Czy filozofię Witkacego można uratować?”. W: Powroty do Witkacego, red. Józef Tarnowski, Słupsk: Muzeum Pomorza Środkowego. 
Tarnowski Józef. 2001. „Filozofia Witkacego - intelektualny żart?”. W: Witkacy w Polsce i na świecie, red. Marta Skwara, Szczecin: Wydawnictwo Naukowe Uniwersytetu Szczecińskiego.

Witkiewicz Stanisław Ignacy. 2002. „Pojęcia i twierdzenia implikowane przez pojęcie istnienia". W: Stanisław Ignacy Witkiewicz. Dzieła zebrane. T. 13, red. Bohdan Michalski, 147-384. Warszawa: PIW.

Witkiewicz Stanisław Ignacy. 2002. „Spór o monadyzm. Dwugłos polemiczny z Janem Leszczyńskim". W: Stanisław Ignacy Witkiewicz. Dzieła zebrane. T. 16, red. Bohdan Michalski, 5-357. Warszawa: PIW.

Witkiewicz Stanisław Ignacy. 2014. „Nauki ścisłe a filozofia”. W: Stanisław Ignacy Witkiewicz, Dzieła zebrane. T. 15, red. Maciej Dombrowski, Magdalena Bizior-Dombrowska, 68-93. Warszawa: PIW.

Witkiewicz Stanisław Ignacy. 2014. „O zjawiskowości tzw. przedmiotu rzeczywistego i fizykalnego". W: Stanisław Ignacy Witkiewicz. Dzieła zebrane. T. 15, red. Maciej Dombrowski, Magdalena Bizior-Dombrowska, 227-269. Warszawa: PIW.

Witkiewicz Stanisław Ignacy, Roman Ingarden. 2002. Korespondencja filozoficzna, red. Bohdan Michalski, Warszawa: IFiS PAN.

\section{Streszczenie}

Artykuł rekonstruuje dwie odmienne interpretacje filozofii czasu i przestrzeni (czaso-przestrzeni) Stanisława Ignacego Witkiewicza - absolutystyczną i relacyjną. Według interpretacji absolutystycznej czas i przestrzeń uznaje się za niezależne od indywiduów. Interpretacja relacyjna natomiast przypisuje prymat bytowy indywiduum, a czas i przestrzeń traktuje jako bytowo zależne. Obie interpretacje zestawiam $\mathrm{z}$ wariantami monizmu podstaw ontologicznych i pluralizmu podstaw ontologicznych, zaczerpniętymi ze współczesnej metafizyki analitycznej. Argumentuję, że interpretacja absolutystyczna w zestawieniu z którymkolwiek z obu stanowisk prowadzi do sprzeczności. W rezultacie konkluduję, że preferowaną interpretacją Witkiewiczowskiej filozofii czasu i przestrzeni jest interpretacja relacjonistyczna.

Słowa kluczowe: S. I. Witkiewicz, czas, przestrzeń, monizm, pluralizm, absolutyzm, relacjonizm 


\section{Summary}

\section{Time and Space in Witkiewicz's Metaphysics and Ontological Priority of Individuals in the Light of Contemporary Analytical Metaphysics}

This paper reconstructs two distinct interpretations of Stanisław Ignacy Witkiewicz's philosophy of time and space and his concept of space-time, absolutist and relational. According to the first one mentioned, both space and time exist independently of individuals, whereas the other assumes the ontological priority of the individuals. The interpretations are associated with variants of priority monism and priority pluralism drawn from the contemporary analytic metaphysics. I argue that the absolutist interpretation ends up in a contradiction, irrespective of which of the two positions is accepted. The conclusion is drawn that it is the relational interpretation of Witkiewicz's philosophy of time and space that should be preferred.

Keywords: S. I. Witkiewicz, time, space, monism, pluralism, absolutism, relationalism 